\title{
Speech and Language Development Patterns of Korean Two-Year-Old Children from Analysis of Spontaneous Utterances
}

\author{
Seunghee $\mathrm{Ha}^{a}$, Ahyoung Seol ${ }^{\mathrm{b}}$, Jungmin $\mathrm{So}^{\mathrm{c}}$, Soyeong $\mathrm{Pae}^{\mathrm{a}}$ \\ ${ }^{a}$ Division of Speech Pathology and Audiology, Audiology and Speech Pathology Research Institute, Hallym University, Chuncheon, Korea \\ ${ }^{b}$ Department of Speech-Language Pathology and Audiology, Graduate School of Hallym University, Chuncheon, Korea \\ 'Department of Computer Engineering, Hallym University, Chuncheon, Korea
}

Correspondence: Soyeong Pae, PhD Division of Speech Pathology and Audiology, Audiology and Speech Pathology Research Institute, Hallym University, 1 Hallymdaehak-gil, Chuncheon 24252, Korea

Tel: +82-33-248-2214

Fax: +82-33-256-3420

E-mail: spae@hallym.ac.kr

Received: January 5, 2016

Revised: February 8, 2016

Accepted: February 11, 2016

We thank Bora Park, Minkyung Pi, Daeun Lee, Haeji Kim, and Somi Jung for their assistance in collecting and analyzing the data.

\begin{abstract}
Objectives: This study obtained quantitative measures reflecting phonological, semantic, syntactic, and morphological aspects of language in Korean two-year-old children from analysis of spontaneous utterances. The study investigated whether there were differences of speech-language development patterns between children age 24-30 months and 31-36 months and between boys and girls based on the aforementioned measures. Methods: Twenty-one typically developing children age 24-30 months and 23 typically developing children age 31-36 months participated in the study. Fifty utterances were collected from the children's interaction with their mothers and analyzed. Consonant inventory, syllable structure, phonological mean length of utterance (PMLU), phonological word proximity (PWP), phonological word correction (PWC), and percentage correct consonants (PCC) were obtained as speech measures. The number of different words (NDW), number of total words (NTW), mean length of utterances in morphemes (MLUm), and mean length of utterances in words (MLUw) were analyzed as language measures using the Korean Language Analysis program. Results: All the speech measures except for PMLU showed significant differences between the children age 24-30 months and 31-36 months. NDW, NTW, and MLUw exhibited significant differences between the two age groups, but MLUm did not show a significant difference. There were no significant differences among any of the speech and language measures between boys and girls. Conclusion: These speech and language measures from analysis of spontaneous utterances can be used as references in identifying speech-language development delay and communication disorders in twoyear-old children.
\end{abstract}

Keywords: Two-year-old, Speech-language development, Milestone, Spontaneous language sample
생후 24개월에서 36개월은 일반적으로 음운, 의미, 형태, 구문을 비롯하여 언어의 모든 면에서 비약적인 발달을 보이는 시기이다. 개 인차가 큰 시기이기는 하지만 24 개월에 이르러서는 일반아동의 대 다수가 표현어휘가 본격적으로 증가하고 단어조합이 활발해지면 서 다양한 문법형태소를 사용하게 된다. 음운적인 측면에서도 통 단어를 단위로 말소리를 산출하는 시기를 지나 50 개 이상의 낱말 을 산출하면서 음절구조와 배열 규칙을 적용하여 개별적인 말소리 를 산출하기 시작하여 본격적으로 음운 습득이 이루어지는 시기
이다. 대다수의 일반아동이 본격적인 말-언어 발달을 보이면서, 표 현언어 발달이 느린 아동과 수용언어를 포함하여 전반적인 의사소 통 발달이 지연된 아동이 보다 더 뚜렷하게 관찰되어 전문적인 언 어평가와 치료에 의뢰되기 시작하는 시기이기도 하다.

2세 한국아동의 일반적인 말-언어발달을 영역별로 살펴보면, 먼 저 의미영역과 관련해서는 8-36개월 사이의 영유아를 대상으로 어 휘 사용력에 대한 규준 자료를 제시하고 있는 한국판 맥아더-베이 츠 의사소통발달 평가(K M-B CDI; Pae \& Kwak, 2011)의 자료를 
살펴볼 수 있겠다. $\mathrm{K} \mathrm{M-B} \mathrm{CDI의} \mathrm{규준} \mathrm{자료에} \mathrm{의하면} \mathrm{남자} \mathrm{아동은}$ 24 개월에는 249 개, 30 개월에는 360 개, 36 개월에는 496 개의 어휘를 표현하는 것으로 나타났다. 여자 아동은 24개월에는 308개, 30 개월 에는 415 개, 36 개월에는 501 개의 어휘를 사용하는 것으로 나타났 다. 2 세 전반에는 여자 아동이 남자 아동보다 높은 어휘력을 보이다 가 2세 후반으로 성장해 나갈수록 여아와 남아가 비슷한 어휘력을 보이는 것으로 나타났다. 종합적으로 생후 24 개월 이후 1 년 동안 약 200 개의 어휘를 새롭게 표현하면서 후반에는 약 500 개의 어휘를 표현하는 것으로 나타났다. 자발화 분석을 통해 2 세 전후반의 어휘 와 음운능력 측정치를 살펴본 Choi, Kim과 Kim (2014)에서는 300 발화를 기준으로 분석한 결과 2 세 전반은 약 200개, 2 세 후반은 약 220 개의 서로 다른 낱말을 산출하였다.

표현어휘가 50 개 이상이 되는 시점이면 아동은 낱말을 조합하여 표현하기 시작하여 구문구조가 외현적으로 나타나기 시작하고 점 진적으로 조사와 어미를 포함한 다양한 문법형태소를 표현하면서 보다 의미적으로 정확하고 긴 발화를 산출한다(Pae, 2006). 일반 아동의 문법형태소 습득 과정을 살펴본 국내연구 중 Lee, Chang, Choi와 Lee (2008)는 현재의 K M-B CDI의 이전 판인 MCDI-K (Pae, 2003)에 제시된 표현어휘목록 가운데 총 30 개의 문법형태소 를 토대로 276 명의 아동을 18 개월부터 36 개월까지 종단관찰하였 다. 18 개월부터 6 개월 간격으로 부모에게 아동의 문법형태소 표현 여부를 조사한 결과 18 개월에는 종결어미는 15 개 중 평균 .41 개, 조 사는 12 개 중 .17 개, 연결어미는 3 개 중 대부분이 거의 사용되지 않 아 소수의 아동만이 문법형태소를 표현하였다. 문법형태소 사용이 점진적으로 증가되어 36 개월에는 종결어미는 평균 12 개, 조사는 9.67 개, 연결어미는 2.15 개를 산출하면서 유의한 증가를 보였고, 표 준편차도 감소해 개인차가 줄어들면서 연구에서 살펴본 문법형태 소가 2 세 후반에는 안정적으로 사용되었다. 아동의 발화자료를 토 대로 문법형태소의 표현을 살펴본 선행연구는 문법형태소의 유형 별로 출현하는 시기는 다양하지만 2 세 전후반에 다양한 조사와 어 미 사용이 활발해진다고 일관성 있게 보고하였다(Lee, 2004; Lee \& Lee, 2006; Seo \& Lee, 1999).

문법형태소의 발달과 더불어 2 세 아동은 점진적으로 길고 복잡 한 문장을 구사한다. 한국 2-4세 아동을 대상으로 발화길이를 조 사한 Kim (1997) 연구에서는 2세 전반과 후반 아동집단의 평균형 태소길이는 각각 $3.01,3.75$ 이고, 평균낱말길이는 각각 $2.27,2.67$ 인 것으로 나타났다. 가장 최근에 보고된 Jung과 Yoon (2013)은 2세 아동이 3.89 의 평균형태소길이, 2.14 의 평균낱말길이를 보이는 것 으로 보고하였다. 또한 Yoon, Kim, Kim, Chang과 Cha (2013) 연구 에서는 100 발화를 분석한 결과 2 세 아동의 평균형태소길이는
4.08 , 평균낱말길이는 2.32 로 나타났다.

최근 자발화 분석을 통해 음운발달을 살펴보는 연구가 증가하면 서 선행연구에서 부족하게 보고되었던 2세 아동의 음운발달에 대한 구체적인 자료들이 제시되고 있다(Choi et al., 2014; Ha \& Hwang, 2013; Moon \& Ha, 2012; Yoon, Kim, \& Kim, 2013). 표현어휘의 증 가와 함께 초기 음운발달이 본격적으로 진행되는 2 세의 음운발달 은 주로 성인의 정확한 산출형태와 직접적으로 비교함으로써 아동 의 수행력을 살펴보는 측정치(예: 자음정확도)와 더불어 자음목록 과 음절구조와 같은 아동의 독립적인 조음음운능력을 반영하는 측정치를 토대로 분석되었다. Ha와 Hwang (2013)의 연구에 따르 면 자음정확도 면에서 2 세 전반에는 평균 $70.29 \%$ 을 보이다가 2세 후반에는 $86.57 \%$ 로 크게 증가하여 대다수의 일반 아동이 3 세 이전 에 정확한 조음능력을 보이는 것으로 나타났다. 초성위치에서의 자음목록 면에서는 1 세 후반에는 파열음과 비음만이 자음목록에 포함되어 평균 10.7 개의 자음목록을 보이다가 2세 전반과 후반에 두드러지게 증가해 각각 $15.90,16.40$ 개로 치조마찰음을 제외한 모 든 음소를 산출하는 것으로 나타났다. 자음정확도, 자음목록과음 절구조 외에 2 세 아동의 조음음운발달 현황을 제시하는 측정치에 는 평균음운길이, 단어단위 근접률, 단어단위 정확률과 같은 단어 단위 음운지표가 있다. 평균음운길이는 아동이 산출한 자음과 모 음에 모두 1점씩 부여한 후에 정확하게 산출한 자음에 1점을 추가 하는 방식으로 계산되어 자음정확도뿐만 아니라 아동이 산출한 단어의 음운구조 복잡성과 길이를 반영한다. 단어단위 근접률은 성인의 정확한 산출형태의 평균음운길이와 비교해서 아동의 평균 음운길이가 어떠한지 살펴볼 수 있는 지표이다. 단어단위 정확률 은 아동이 산출한 전체 단어 중 정확하게 산출된 단어의 비율을 의 미한다. 이러한 단어단위 음운지표는 분절음 수준이 아닌 통단어 수준에서 말소리를 산출하는 1-2어 조합기에 있는 아동의 조음음 운능력을 살펴보기에 타당한 측정치이다(Ha \& Hwang, 2013; Ingram, 2002; Ingram \& Ingram, 2001; Yoon, Kim, \& Kim, 2013). Yoon 등(2013) 연구에서는 자발화의 어절을 분석단위로 했을 때 2 세 전반과 후반의 평균음운길이가 각각 평균 $6.37,6.87$ 로 나타났 다. 또한 2 세 전반과 후반의 단어단위 근접률은 각각 $.86, .89$ 로 단 어단위 정확률은 각각 $.45, .53$ 으로 나타나, 2 세 일반아동은 산출한 단어 중 $40 \%-50 \%$ 를 정확하게 조음하는 것으로 나타났다.

자발화 분석을 토대로 아동의 말-언어발달을 살펴보는 연구가 지속적으로 이루어지고 있고, 특히 조음음운영역에서 최근 연구가 보다 활발하게 이루어지고 있다. 하지만 대부분 월령집단별 10 명 내외로 소수의 아동들을 대상으로 수집된 자료를 토대로 하고 있 어 말-언어평가의 규준자료로 사용되기에는 제한적이다. 또한 어휘 
와 문법형태소 발달과 관련된 자료는 K M-B CDI 검사와 같이 주 로 아동의 주 양육자가 제시된 어휘체크리스트를 보고 일상생활에 서 아동이 표현하고 이해한 어휘를 회상하여 체크하는 형식을 통 해서 제시되었다. 따라서 아동의 언어발달 상황을 정확하게 평가하 기 위해서는 주 양육자의 객관적이고 일관된 보고능력을 기본 전 제로 해야 한다(Pae, Chang, Kwak, Sung, \& Sim, 2004). 이러한 검 사방법의 제한점을 보여주는 예로서 Choi 등(2014)의 연구에서는 $\mathrm{K} \mathrm{M}-\mathrm{B} \mathrm{CDI}$ 검사의 표현어휘 검사결과가 자발화에서 측정된 음운 능력 지표들뿐만 아니라 어휘 능력을 나타내는 지표와도 유의미한 상관관계를 보이지 않는 것으로 나타났다. 또한 통계적으로는 유의 미한 차이는 없었지만, 기술통계 결과값을 살펴보면 2 세 후반이 2 세 전반보다 낮은 평균 어휘 수를 보였다. 이러한 결과는 선행연구 에서 모집된 아동집단의 특성과 개인차로 인한 것일 수도 있겠지만 연구자들이 논하였듯이 부모보고에 의한 평가 방식이 신뢰롭지 못 하게 진행되었을 가능성이 있고, 보고자가 아동의 어휘능력을 과 소 또는 과대평가했을 수 있다. 따라서 아동의 실제적인 말-언어능 력을 보다 정확하게 살펴보기 위해서는 아동이 직접적으로 산출한 발화에 대한 분석이 보완적으로 이루어져야 한다.

자발화에 근거한 자료수집과 분석은 부모보고에 의거한 평가방 식을 보완하는 장점이 있으나, 자발화를 수집하고 전사하며 분석 하는 과정에서 시간이 많이 걸리거나 상호작용 도구와 방식에 따라 그 결과가 달라지는 단점이 있다(Paul \& Norbury, 2012). 자발화 분 석의 효율성을 높이기 위해 사용하는 방식으로 컴퓨터 프로그램 의 도움을 받을 수 있는데, Systematic Analysis of Language Transcripts (SALT)는 미국에서 언어치료사가 임상과 연구에서 가장 많 이 사용하는 프로그램이다. SALT는 녹음된 아동의 발화자료를 전 사자가 전사 및 코딩을 한 뒤 분석프로그램을 실행시키면 평균발 화길이와 같은 객관적인 언어발달 측정치를 자동으로 계산한다. 따라서 아동의 언어발달 현황과 장애 여부에 대한 정보를 쉽고 빠 르게 제시해 줄 수 있다는 장점이 있다. 한국어의 경우 발화분석의 효율성을 높이기 위해 소프트웨어가 개발된 적이 있으나(Pae, Kim, Sung, \& Sung, 1998), 언어임상 현장에서 상용화되지는 못하였다. 이에 본 연구자들은 분석의 효율성을 높이기 위해 웹 기반 한국어 발화 분석(Korean Language Analysis, KLA) 소프트웨어를 개발 하여 사용하였다.

현재 생후 4 개월부터 71 개월까지의 영유아를 대상으로 실시되 고 있는 영유아건강검진을 통해 과거보다 발달상의 문제를 보일 가 능성이 높은 아동이 일찍 확인되고 있다. 영유아건강검진에서는 양육자가 검사항목을 읽고 체크하는 형식인 한국 영유아발달선별 검사(K-DST)를 통해 영유아의 신체운동, 인지, 사회성 및 언어기
술을 포함한 전반적인 발달 현황을 살펴보고 있다. 이 검사를 통해 말-언어발달지연 및 의사소통장애 고위험군으로 의심되는 어린 연 령의 아동들이 확인되고 있어 전문적인 말-언어평가에 의뢰되는 아동의 비율이 과거보다 증가하고 있다(Kim, Kim, Ha, \& Ha, 2015). 따라서 말-언어발달지연 및 의사소통장애를 조기에 정확하게 확인 하고 진단할수 있는 발달자료가 필요하다. 특히 2세 아동의 실제적 인 발화 자료를 토대로 한 측정치는 언어중재서비스의 필요성을 보 다 정확하게 결정하는 데 유용한 자료가 될 수 있다. 본 연구는 자발 화 분석을 통해 음운, 의미, 구문, 형태론을 나타내는 객관적인 지표 를 토대로 2 세 한국아동의 말-언어발달 특성을 자세히 살펴보고자 한다. 구체적으로 2세는 말-언어발달이 가장 빠르고 활발하게 이루 어지는 시기 중 하나이고 개인차가 큰 시기이므로 발달 특성을 자 세히 분석하고자 객관적인 말-언어 측정치가 2 세 전반과 후반의 월 령집단과 성별에 따라 다른지 살펴보고자 한다. 또한 아동의 자발 화 분석을 용이하게 하기 위해 개발된 $\mathrm{KLA}$ 를 이용해서 객관적인 측정치를 제시하면서 프로그램의 효율성을 소개하고자 한다.

\section{연구 방법}

\section{연구대상}

본 연구는 서울 및 강원지역에 거주하는 24-36개월의 영유아를 대상으로 실시되었으며, 아동을 24-30개월과 31-36개월로 2세 전 반과 후반 집단으로 구분하였다. 참여한 영유아는 (1) 부모보고에 의해 출생과 발달상에 뚜렷한 문제나 결함을 보이지 않았고, (2) 시 각 및 청각 등 감각장애와 정서 및 행동장애가 의심되지 않은 아동 이었다. 맥아더-베이츠 의사소통발달 평가(KM-B CDI; Pae \& Kwak, 2011)를 실시하여 표현어휘에서 $10 \%$ ile 이하인 아동 3명과 자발화 수집에서 산출된 발화 수가 10 개 미만인 아동 2 명을 제외하여 2 세 전반은 21 명, 2 세 후반은 23 명으로 총 44 명이 연구에 참여되었다. 월령집단별 영유아 정보는 Table 1과 같다.

\section{자료수집}

자료 수집은 훈련된 검사자가 각 가정을 방문하여 책과 놀잇감

Table 1. Subjects' information

\begin{tabular}{lcc}
\hline Age group & $M$ & SD \\
\hline $24-30$ mo & & \\
Boy $(N=10)$ & 28.10 & 2.08 \\
Girl $(N=11)$ & 26.36 & 1.75 \\
$31-36$ mo & & \\
Boy $(N=7)$ & 34.43 & 2.08 \\
Girl (N=16) & 33.81 & 3.31 \\
\hline
\end{tabular}


을 이용한 자유놀이 상황을 활용하였다. 영유아는 주 양육자와 20 분간 상호작용 놀이에 참여하였다. 모든 영유아에게 책 2 권을 5 분 동안 제공하였으며, 이후 15 분 동안 자동차, 블록놀이, 소꿉놀이, 낚시놀이를 동일하게 제공하였다. 자료수집 전 양육자에게 평상시 와 동일하게 상호작용하도록 지시하였다. 모든 자료는 녹화 및 녹 음을 실시하였다.

\section{자료분석}

수집된 35 분의 상호작용 자료는 수집 후 2 주일 내에 비디오 자료 를 바탕으로 전사하였다. 아동 발화 전사에 대해 훈련을 받은 언어 병리학 학부생 5 명이 비디오 영상을 보며 1차적으로 전사를 한 후, 언어병리학 대학원생 1 인이 음성 녹음된 자료를 들으면서 바르게 전사되었는지 재확인하였다. 모든 전사자료는 한글전사를 실시하 였으며, 이후 말지표 분석을 위해 녹음자료를 다시 들으면서 말장 애 전공 언어병리학 대학원생 1 인이 음성전사를 실시하였다. 발화 구분 기준은 $\operatorname{Kim}$ (1997) 연구를 바탕으로 하였다. 모든 자료에서 단순한 대답하기 기능으로 사용하는 '네', 응'은 첫 번째로 산출된 것만 포함시켰고, 초기발성과 자곤 등과 같은 의미가 불명료한 발 화와 감탄사 '아' 등은 분석에서 제외하였다. 아동의 발화는 어머니 와의 상호작용에서 산출한 연속적인 50 발화를 기준으로 하였다. 발화 수가 40-49개인 9명의 아동도 포함하여 총 44명의 자료를 분 석하였다. 2 세 전반은 평균 발화 수 45.71 (7.72)개, 2 세 후반은 평균 발화 수 47.74 (5.21)개로 통계적으로 유의한 차이를 보이지 않았다 $(t=-1.028, p>.05)$.

다양한 객관적인 지표를 토대로 언어발달지연 여부와 월령에 따 른 아동의 말-언어 발달을 살펴보았다.

\section{말 지표}

아동의 자발화를 토대로 객관적인 말 지표로서자음목록(초성, 종 성, 전체), 음절구조유형 수, 평균음운길이(phonological mean length of utterance, $\mathrm{PMLU}$ ), 단어단위 근접률(phonological word proximity, $\mathrm{PWP}$ ), 단어단위 정확률(phonological word correction, PWC), 자음 정확도(percentage correct consonants, PCC)를 분석하였다.

자음목록은 산출된 전체 자음을 초성과 종성 위치별로 분류한 뒤 서로 다른 2 개 이상의 낱말에서 산출된 자음만을 자음목록에 포함시켰다(Stoel-Gammon, 1985). 음절구조 유형 수는 한국어에 서 가능한 음절구조 형태 8 가지(V, GV, CV, CGV, $\mathrm{VC}, \mathrm{GVC}, \mathrm{CVC}$, $\mathrm{CGVC}$; $\mathrm{V}=$ 모음, $\mathrm{C}=$ 자음, $\mathrm{G}=$ 활음) 중 아동이 산출한 음절구조 의 유형 수를 분석하였다. PMLU, PWP, PWC, PCC의 분석은 기본 적으로 Ingram (2002)과 Shriberg와 Kwiatkowski (1982)가 제안한
것을 토대로 분석하였지만 자발화에서의 조음능력을 좀 더 타당하 게 반영하는 어절을 기본 단위로 분석하였다. 심 없이 연속적인 조 음이 나타날 수 있는 수사와 의존명사(예: 한 개), 본 용언과 보조용 언(먹어 봐), 의존명사가 포함된 어절(예: 할 수 있어) 등은 한 어절로 간주하였다(Ha \& Hwang, 2013; Kim, 2014). PMLU는 성인의 정확 한 발음형태를 기준으로 각 어절별로 아동이 산출한 음소 수에 정 조음한 자음의 개수를 합산하여 계산한 후에 전체 어절의 수로 나 누어 계산하였다. PWP는 아동의 PMLU를 성인의 정확한 산출형 태의 PMLU로 나누어 계산하였고 PWC는 아동이 정확하게 산출 한 어절 수를 산출한 전체 어절로 나누어서 계산하였다. PCC 분석 은 목표자음에 대해서만 고려하였으며 목표자음을 생략, 대치, 왜 곡한 오류에 대해서는 모두 오조음으로 분석하여 정조음한 자음 수를 총 목표자음 수로 나누어 백을 곱하여 계산하였다.

\section{언어지표}

언어지표는 본 연구자들이 개발한 한국어 발화 분석(KLA) 프 로그램을 통해 분석되었다. KLA는 발화를 분석할 수 있는 컴퓨터 프로그램으로 아동의 발화를 프로그램에 입력한 후 낱말은 띄어 쓰기로, 문법형태소는/로 경계를 표시한다. 서로 다른 낱말은 한 어 절을 구성하는 내용낱말(예: 명사, 부사, 동사, 형용사 등)을 위주로 계산하며, 평균낱말길이(mean length of utterance in morphemes, $\mathrm{MLUw}$ )는 어절을 경계로, 평균형태소길이(mean length of utterance in words, MLUm)는 형태소를 기준으로 분석한다. 아동의 발 화에서 의미오류, 문법형태소오류, 조음오류가 있을 때는 의미, 문 법형태소, 조음오류를 바르게 입력한 후 단어 뒤에 의미오류일 경 우에는 [실의], 문법형태소오류일 경우에는 [실형], 조음오류일 경 우에는 [실음]으로 표기한다. 표기를 하고 실제 아동의 발화를 입 력한 후 어떠한 오류를 보였는지 $=$ 표시를 한 후 기록한다.

아동의 발화에서 반복, 수정, 감탄사는 ( )에 넣는다. ( ) 안에 들어 간 발화는 분석에서 제외된다. 분석이 완료되면 전체 발화 수, 이해 가능 발화 수, 어절별 이해가능 발화 수, 낱말 유형 수, 낱말 빈도수, 문법형태소 유형 수, 문법형태소 빈도수, 형태소 유형 수, 형태소 빈 도수가 자동으로 계산되어 보여준다. 본 연구에서는 $\mathrm{KLA}$ 를 통해 서로 다른 낱말 수(number of different words, NDW), 총 사용 낱 말 수(number of total words, NTW), MLUm, MLUw를 분석하였 다. 아동의 발화를 입력한 예는 Figure 1과 같다.

모든 언어 지표는 1 차적으로 50 발화를 기준으로 분석하였으며, MLUm과 MLUw는 아동이 가장 길게 산출한 10 발화를 토대로 추 가적으로 분석하였다. 아동이 산출한 가장 긴 10 발화를 추가로 분 석한 이유는 부모보고나 발화수집 과정에서 초기 언어발달기 문법 

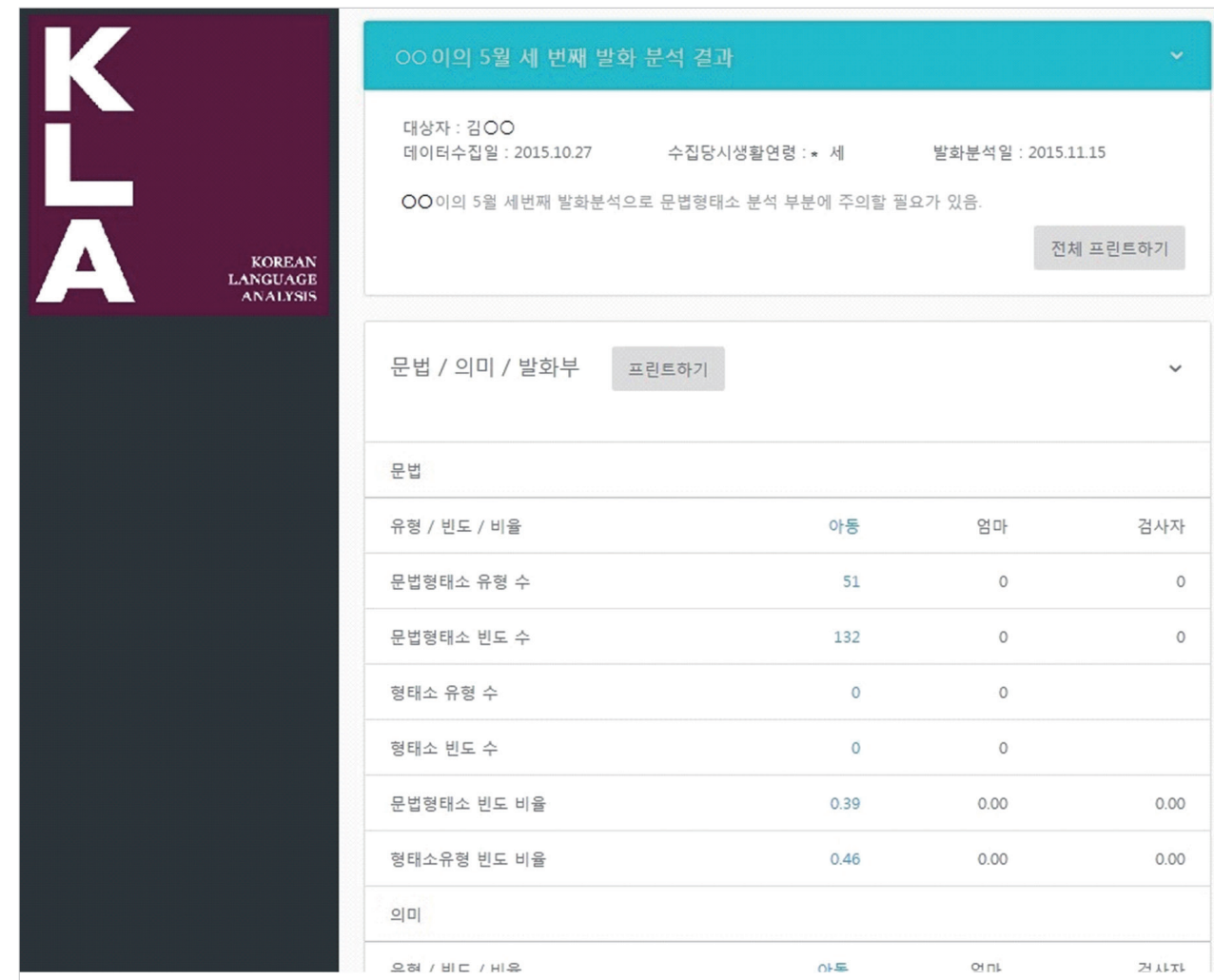

바로보기에뉴

대상자 : 김ㅇㅇ

데이터수집일 : 2015.10.27 수집당시생활연령 : * 세벨화분석일 : 2015.11.15

$\mathrm{OO}$ 이의 5 월 세번째 발화분석으로 문볍형태소 분석 부분에 주의할 필요가 있음

\section{전체 프린트하기}

문법 / 의미 / 발화부

\section{프린트하기}

\section{분석결과목록}

문법 / 의미 / 발화부

아동전체 발화목록

어절수별 발화목록

낱말목록

문법형태소목록

미있는 발화목록

$$
\text { 문법 }
$$

$\begin{array}{llll}\text { 유형 / 빈도 / 비율 } & \text { 아동 } & \text { 엄마 } & \text { 검사자 }\end{array}$

문법형태소 유형 수

문법형태소 빈도 수

51

형태소 유형 수

형태소 빈도 수

문법형태소 빈도 비율

형태소유형 빈도 비율

의미

으혀 / 비드 / 비응

어 ni

거사자

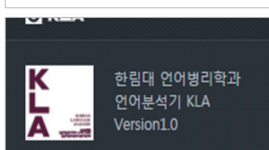

(소 홈 - 신규발화분석

\section{슨 소개 및 분석방법 \\ 신규발화분석 \\ :三 분석결과관리 \\ 2 대상자관리 \\ (2) QRA}

대상자등록 및 수정

대상자선택

발화분석대상을 선택하세요

대상자 등록 밎 관리는 좌측 "대상자관리"메뉴에서 하실 수 있습니다

\begin{tabular}{|c|c|}
\hline 일/월/생년 & 성별 \\
\hline $23 / 11 / 2010$ & $\odot$ 남 $\bigcirc$ 여 \\
\hline
\end{tabular}

발화데이터 수집일

苗

전사데이터 파일 업로드

No file selected

전사데이터 작성안내

전사데이터

아 애 버스

아 싫어[실음]

아 싫어실음]
=[실음]시어

아 수박[실음]

=[실음]수아

아 (우와) 이거 뭐/지?

아 이거 그네실의]

=[실의] 시소

Figure 1. Korean Language Analysis (KLA) program. 
을 살피기 위해 가장 긴 3-10 발화를 이용하여 분석하는 방법이 효율 적이라는 선행연구(Andonova, 2015; de Haan \& Singer, 2010; Harris, Jones, Brookes, \& Grant, 1986; Trudeau \& Sutton, 2011)의 제안에 따 라 50 발화분석결과와 비교하기 위해 시범적으로 분석하였다.

\section{신뢰도}

언어병리학전공 대학원생 2 명이 전체 자료 중 $10 \%$ 를 임의로 선 정하여 전사신뢰도 및 말지표와 언어지표의 신뢰도를 구하였다. 전 사신뢰도는 (일치한 자음 수/전체 자음 수) $\times 100$ 으로 계산하였다. 그 결과, $91.03 \%$ 였다. 말지표는 2 명의 분석자가 각 종속치의 신뢰도 를 구하였다. Cohen's Kappa를 이용하여 평가자 간 신뢰도를 측정 하였다. 그 결과 PMLU .994, PWP .994, PWC .948, PCC .997, 음절 유형 목록 수 1.000 , 초성 자음 목록 수 .986 , 종성 자음 목록 수 .929 , 전체 자음 목록 수 .973 으로 높은 평가자 간 신뢰도를 갖는 것 으로 나타났다.

$\mathrm{KLA}$ 프로그램은 전사자가 입력한 전사내용을 토대로 자동으로 언어측정치를 분석하여 제시하는 프로그램이므로 전사자료코딩 의 정확도가 중요하다. 따라서 낱말과 문법형태소의 경계와 관련된 코딩의 일치도를 통해 언어지표의 검사자 간 신뢰도를 살펴보았다. 그 결과 두 전사자 간 내용 및 문법형태소의 코딩 일치도는 $97.38 \%$ 로 나타났다.

\section{통계처리}

월령집단과 성별에 따른 아동의 말 특성과 언어적 특성을 알아 보기 위해 SPSS 21.0 프로그램을 사용하여 이원분산분석(two-way ANOVA)을 실시하였다.

Table 2. Descriptive analysis of syllable types and consonant inventory between the two age groups

\begin{tabular}{lcccc}
\hline \multirow{2}{*}{ Age group } & \multirow{2}{*}{$\begin{array}{c}\text { Types of sylla- } \\
\text { ble structure }\end{array}$} & \multicolumn{3}{c}{ Inventory of consonant } \\
\cline { 3 - 5 } & & & Final & Total \\
\hline $24-30$ mo & & & \\
Boy & $6.20(1.03)$ & $11.90(3.11)$ & $3.00(1.41)$ & $13.10(3.07)$ \\
Girl & $6.09(.94)$ & $10.27(3.35)$ & $3.27(1.49)$ & $11.27(3.20)$ \\
Total & $6.14(.94)$ & $11.05(3.26)$ & $3.14(1.42)$ & $12.14(3.20)$ \\
31-36 mo & & & & \\
Boy & $6.57(.98)$ & $12.86(1.68)$ & $4.29(.76)$ & $13.86(1.35)$ \\
Girl & $7.07(.68)$ & $13.94(2.08)$ & $4.88(.89)$ & $15.00(1.97)$ \\
Total & $6.91(.79)$ & $13.61(1.99)$ & $4.79(.88)$ & $14.65(1.85)$ \\
Total & & & & \\
Boy & $6.35(.10)$ & $12.29(2.59)$ & $3.53(1.33)$ & $13.41(2.48)$ \\
Girl & $6.67(.92)$ & $12.44(3.19)$ & $4.22(1.40)$ & $13.48(3.11)$ \\
Total & $6.55(.95)$ & $12.39(2.94)$ & $3.95(1.40)$ & $13.45(2.85)$ \\
\hline
\end{tabular}

Values are presented as mean (SD).

\section{연구 결과}

\section{말 특성}

음절구조 유형 수, 자음목록(초성, 종성, 전체) 수를 토대로 2세 아동의 말 특성을 살펴본 결과는 Table 2 와 같다. 음절구조 유형 수 는 2 세 전반에는 평균 6.14 개, 2 세 후반에는 평균 6.91 개로 산출하 는 음절구조 유형은 유사하였고, 성별에 따라서도 남아 평균 6.35 개, 여아 평균 6.67개로 유사하였다. 월령과 성별에 따라 유의한 차 이를 보이는지 알아보기 위해 이원분산분석을 실시한 결과, 음절 유형 목록 수는 월령에 따라 유의한 차이를 보였고 $(F=5.843, p<$ $.05)$, 성별 $(F=.473, p>.05)$ 과 상호작용효과 $(F=1.167, p>.05)$ 는 유 의미하지 않았다. 8 가지 한국어 음절구조 중에서 2 세 전반과 후반 아동 모두 CV 구조를 50\% 이상으로 가장 높은 비율로 산출하였 고, 그 다음으로 V와 CVC가 $10 \%$ 대의 비율을 차지하였다. 모든 음 절구조 유형 수가 두 월령집단에 의해 비슷한 비율로 산출되어 2세 아동 전체가 산출한 각각의 음절구조가 차지하는 비율을 Figure 2 에 나타내었다.

자음목록 전체로 보았을 때 2 세 전반에는 평균 12.14 개, 2 세 후 반에는 평균 14.65 개로 월령이 증가함에 따라 산출되는 자음의 수 가 많았고 남아와 여아 모두 평균 13.45 개 정도로 유사하였다(Table 2). 자음목록에 대한 이원분산분석 결과, 초성 자음 유형은 월 령에 따라 유의한 차이를 보였으나 $(F=7.677, p<.01)$, 성별 $(F=.107$, $p>05)$ 과 상호작용효과 $(F=2.635, p>.05)$ 는 유의하지 않았다. 종성 자음 유형은 월령에 따라 유의한차이를 보였고 $(F=15.208, p<.001)$, 성별 $(F=1.355, p>.05)$ 과 상호작용효과 $(F=.183, p>.05)$ 는 유의하 지 않았다. 전체 자음 목록 수에서도 마찬가지로 월령에 따라서만

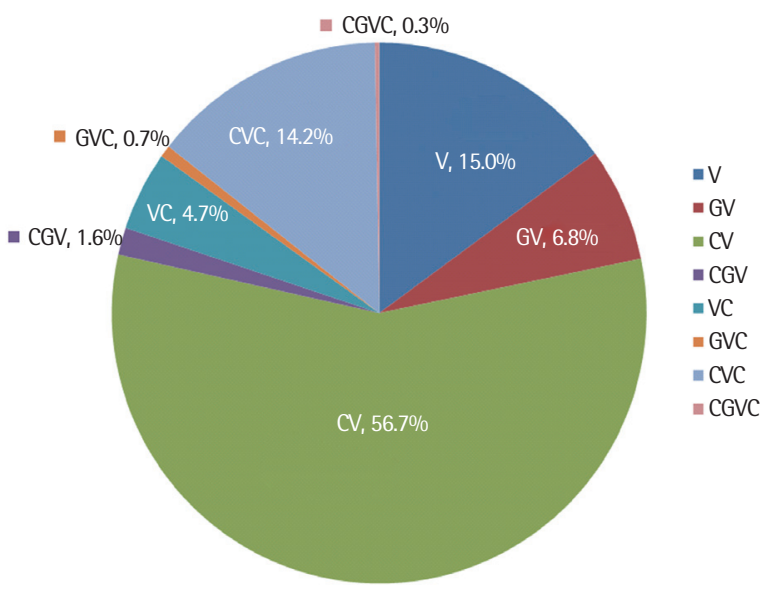

Figure 2. The ratio of each syllable structure type produced by Korean twoyear-old children. $\mathrm{V}=$ vowel; $\mathrm{G}=$ glide; $\mathrm{C}=$ consonants. 
유의한 차이를 보였다 $(F=7.931, p<.01)$.

2 세 전반과 후반 아동의 $50 \%$ 이상 자음목록에 포함된 음소들은 Table 3에 제시하였다. 자음목록 중 초성은 2세 전반에는 평균 11.05 개로 2 세 전반 아동의 $50 \%$ 이상 초성 자음목록에 포함된 음소로 는 조음 방법 면에서 파열음/프/, 마찰음/씨를 제외한 모든 초성 자음을 산출하였고, 2 세 후반에는 평균 13.16개로 파열음, 마찰음, 파찰음, 비음, 유음의 모든 초성 자음을 산출하여 월령이 증가함에 따라 산출되는 초성 자음의 수가 증가하였다. 성별에 따라서는 남 아 평균 12.29개로 파열음 / 프/, 마찰음 / ㅆ/를 제외한 모든 초성 자 음을 산출하였고, 여아는 평균 12.44개로 마찰음 / 씨를 제외한 모 든 초성 자음을 산출하였다. 종성 자음목록 수는 2 세 전반에는 평 균 3.14 개로 2 세 전반 아동의 $50 \%$ 이상에게서 비음, 유음이 관찰되 었고, 2 세 후반에는 평균 4.79 개로 종성파열음이 추가되는 모습이 관찰되었다.

PMLU, PWP, PWC, PCC를 토대로 2세 아동의 말 특성을 살펴 본 결과는 Table 4 와 같다. PMLU는 2세 전반 평균 5.91, 2세 후반

Table 3. Phones in consonant inventories of $50 \%$ of two-year-old subjects

\begin{tabular}{|c|c|c|}
\hline Gender & Initial & Final \\
\hline Boy & 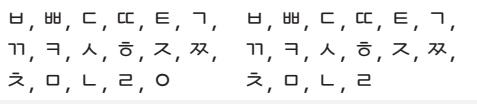 & ᄃ, ᄀ, , ᄂ, o, ᄅ \\
\hline Girl & 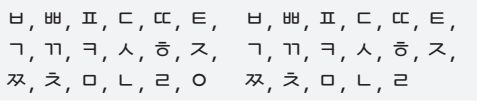 & ᄀ, ㄴ, ᄂ, ०, ᄅ \\
\hline Total & 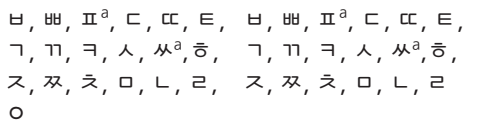 & $\begin{array}{l}\forall^{a}, \subset^{a}, \neg^{a}, \square,\llcorner, \\
0, \text { ¿ }\end{array}$ \\
\hline
\end{tabular}

aConsonants which were added by $50 \%$ of 30 - to 36 -month-old children.

Table 4. Descriptive analysis of syllable types and consonant inventory between the two age groups

\begin{tabular}{lllll}
\hline Age group & \multicolumn{1}{c}{ PMLU } & PWP & PWC & PCC \\
\hline 24-30 mo & & & & \\
Boy & $5.81(1.28)$ & $.86(.06)$ & $.59(.13)$ & $72.95(7.99)$ \\
Girl & $5.99(.89)$ & $.85(.06)$ & $.52(.09)$ & $73.46(7.33)$ \\
Total & $5.91(1.07)$ & $.86(.06)$ & $.55(.12)$ & $73.22(7.46)$ \\
31-36 mo & & & & \\
Boy & $6.15(.61)$ & $.88(.07)$ & $.62(.18)$ & $76.76(11.75)$ \\
Girl & $6.67(.89)$ & $.93(.06)$ & $.72(.17)$ & $86.08(11.04)$ \\
Total & $6.58(.86)$ & $.92(.07)$ & $.69(.17)$ & $83.25(11.83)$ \\
Total & & & & \\
Boy & $5.95(1.04)$ & $.87(.06)$ & $.60(.15)$ & $74.52(9.56)$ \\
Girl & $6.45(.96)$ & $.90(.07)$ & $.64(.15)$ & $80.94(11.44)$ \\
Total & $6.26(1.01)$ & $.89(.69)$ & $.63(.16)$ & $78.46(11.10)$ \\
\hline
\end{tabular}

Values are presented as mean (SD).

$\mathrm{PMLU}=$ phonological mean length of utterance; $\mathrm{PWP}=$ phonological word proximity; $\mathrm{PWC}=$ phonological word correction; $\mathrm{PCC}=$ percentage correct consonants.
평균 6.58 로 나타났고, 성별에 따라서는 남아 평균 5.95 , 여아 평균 6.45로 나타났다. PWP는 2세 전반은 평균 $.86,2$ 세 후반은 평균 .92 로 월령이 증가함에 따라 증가하였고 성별에 따라서는 남아 평균 .87 , 여아 평균 .90 으로 여아가 다소 높았다. PWC는 2 세 전반 평균 $.55,2$ 세 후반 평균 .69로 월령이 증가함에 따라 증가하였고, 성별에 따라서는 남아 평균 .60, 여아 평균 .64로 유사하였다. PCC는 2세 전반 평균 73.22,2세 후반 83.25로 월령이 증가함에 따라 증가하였 고, 성별에 따라서는 남아 평균 74.52 , 여아 평균 80.94 로 여아의 자 음정확도가 높았다. 월령과 성별에 따라 말 지표가 통계적으로 유 의한지 알아보기 위해 이원분산분석을 실시한 결과, PMLU는 월 령집단 $(F=3.382, p>.05)$ 과 성별 $(F=1.755, p>.05)$ 에 따라 유의한 차이가 없었고, 상호작용효과도 나타나지 않았다 $(F=.506, p>.05)$. PWP는 월령집단에 따라 유의한 차이가 있었으나 $(F=5.466, p<.05)$, 성별에 따라서는 유의한 차이가 나타나지 않았다 $(F=1.345, p>.05)$. 상호작용효과도 나타나지 않았다 $(F=1.696, p>.05)$. $\mathrm{PWC}(F=6.334$, $p<.05)$ 와 PCC $(F=2.591, p<.05)$ 도 월령집단에 따라서만 유의한 차이가 있었다.

\section{언어적 특성}

2세 아동의 언어적 특성 중 어휘 영역과 관련하여 NDW와 NTW 을 살펴본 결과는 Table 5 와 같다. NDW는 2 세 전반 평균 32.38 개, 2세 후반 평균 47.57개로 월령이 증가함에 따라 사용하는 낱말 수 도 증가하였고, 성별에 따라서는 남아 평균 35.12 개, 여아 평균 43.59 개로 여아가 더 많은 서로 다른 낱말을 사용하였다. NTW는 2세 전 반 평균 61.81 개, 2 세 후반 평균 80.35 개로 월령이 증가함에 따라 발 화 내 총 사용 낱말 수가 많았고, 성별에 따라서는 남아 평균 69.06 개, 여아 평균 73.04개로 여아의 총 사용 낱말 수가 많았다. 이 차이

Table 5. Descriptive analysis of NDW and NWT in 50 utterances between the two age groups

\begin{tabular}{lcc}
\hline Age group & NDW & NWT \\
\hline $24-30$ mo & & \\
Boy & $32.10(10.69)$ & $61.70(15.74)$ \\
Girl & $32.64(12.64)$ & $61.91(22.91)$ \\
Total & $32.38(11.47)$ & $61.81(19.34)$ \\
$31-36$ mo & & \\
Boy & $39.43(9.09)$ & $79.57(17.72)$ \\
Girl & $51.13(21.96)$ & $80.69(24.48)$ \\
Total & $47.57(19.54)$ & $80.35(23.75)$ \\
Total & & \\
Boy & $35.12(10.45)$ & $69.06(18.42)$ \\
Girl & $43.59(20.63)$ & $73.04(26.36)$ \\
Total & $40.32(17.76)$ & $71.50(23.46)$ \\
\hline
\end{tabular}

Values are presented as mean (SD).

NDW = number of different words; NWT = number of total words. 
Table 6. Descriptive analysis of MLUm and MLUw in 50 and longest 10 utterances between the two age groups

\begin{tabular}{cccccc}
\hline \multirow{2}{*}{ Age group } & \multicolumn{2}{c}{50 Utterances } & & \multicolumn{2}{c}{ Longest 10 utterances } \\
\cline { 2 - 3 } \cline { 5 - 6 } & MLUm & MLUw & & MLUm & MLUw \\
\hline 24-30 mo & & & & \\
Boy & $1.73(.54)$ & $1.32(.23)$ & & $3.50(1.26)$ & $2.43(.83)$ \\
Girl & $2.06(.49)$ & $1.46(.27)$ & & $4.06(2.06)$ & $2.64(1.22)$ \\
Total & $1.90(.53)$ & $1.39(.26)$ & & $3.80(1.71)$ & $2.54(1.03)$ \\
31-36 mo & & & & & \\
Boy & $2.21(.81)$ & $1.58(.39)$ & & $4.99(1.69)$ & $3.21(1.04)$ \\
Girl & $2.48(2.40)$ & $1.74(.52)$ & & $6.48(2.82)$ & $4.03(1.63)$ \\
Total & $2.40(.95)$ & $1.69(.48)$ & & $6.02(2.59)$ & $3.78(1.50)$ \\
Total & & & & & \\
Boy & $1.93(.69)$ & $1.43(.32)$ & & $4.11(1.59)$ & $2.75(.97)$ \\
Girl & $2.31(.86)$ & $1.62(.45)$ & & $5.49(2.77)$ & $3.46(1.61)$ \\
Total & $2.16(.81)$ & $1.55(.41)$ & & $4.96(2.46)$ & $3.19(1.43)$ \\
\hline
\end{tabular}

Values are presented as mean (SD).

$M L U m=$ mean length of utterance in morphemes; MLUw= mean length of utterance in words.

가 통계적으로 유의한지 알아보기 위해 이원분산분석을 실시한 결 과, NDW는 월령에 따라서는 유의한 차이가 나타났으나 $(F=6.495$, $p<.05)$, 성별 $(F=1.458, p>.05)$ 과 상호작용은 통계적으로 유의하 지 않았다 $(F=1.214, p>.05)$. NTW는 월령에 따라 유의한 차이가 나타났고 $(F=6.821, p<.05)$, 성별에 따라서는 유의한 차이가 나타 나지 않았다 $(F=.009, p>.05)$. 상호작용효과도 나타나지 않았다 $(F=.004, p>.05)$.

월령집단에 따른 MLUm, MLUw에 대한 기술통계 결과는 Table 6과 같다. 50 발화를 기준으로 평균형태소길이(MLUm)와 평균낱 말길이(MLUw)를 분석한 결과, MLUm은 2세 전반 평균 1.90, 2 세 후반 평균 2.40 으로 나타났고, 성별에 따라서는 남아 평균 1.93 , 여 아 평균 2.31로 나타났다. 평균낱말길이(MLUw)는 2세 전반 평균 $1.39,2$ 세 후반 평균 1.69 로 나타났고 성별에 따라서는 남아 평균 1.43 , 여아 평균 1.62 로 나타났다. 이원분산분석을 실시한 결과, MLUm 은 월령집단에 따라 유의한 차이가 없었고 $(F=3.386, p>.05)$, 성별 에 따라서도 유의한 차이가 나타나지 않았다 $(F=1.485 p>.05)$. 상 호작용 효과도 나타나지 않았다 $(F=.016, p>.05)$. MLUw는 월령집 단에 따라 유의한 차이가 있었고 $(F=4.725, p<.05)$, 성별에 따라서 는 유의한 차이가 나타나지 않았다 $(F=1.474 p>.05)$. 상호작용 효 과는 나타나지 않았다 $(F=.010, p>.05)$

아동이 산출한 50 발화 중 가장 긴 10 발화를 기준으로 MLUm 과 $\mathrm{MLUw}$ 를 분석한 결과, MLUm은 2세 전반 평균 3.80, 2 세 후반 평균 6.02 로 평균형태소길이가 증가하였고, 성별에 따라서는 남아 4.11 , 여아 5.49 로 여아의 평균형태소길이가 길었다. MLUw는 2 세 전반 평균 $2.54,2$ 세 후반 평균 3.78 로 월령에 따라 길이가 증가하였
고, 성별에 따라서는 남아 평균 2.75 , 여아 평균 3.46 으로 여아의 평 균낱말길이가 길었다. 이 차이가 통계적으로 유의한지 알아보기 위 해 이원분산분석을 실시한 결과, MLUm은 월령집단에 따라 유의 한 차이가 있었고 $(F=7.930, p<.01)$, 성별에 따라서는 유의한 차이 가 없었다 $(F=2.191, p>.05)$. 상호작용효과도 나타나지 않았다 $(F=$ $.444, p>.05)$. MLUw은 월령집단에 따라 유의한 차이가 있었고 $(F=7.086, p<.05)$, 성별에 따라서는 유의한 차이가 나타나지 않았 다 $(F=1.582, p>.05)$. 상호작용효과는 나타나지 않았다 $(F=.566$, $p>.05)$.

\section{논의 및 결론}

본 연구는 자발화 분석을 통해 측정된 객관적 지표를 바탕으로 24-30개월과 31-36개월 집단과 성별 간 차이를 보면서 만 2세 한국 아동의 음운, 의미, 구문, 형태론적인 언어발달 특성을 자세히 살펴 보고자 하였다. 먼저 음운발달과 관련해서 아동의 독립적인 조음 음운능력을 반영하는 측정치인 음절구조 유형 수와 자음목록을 구하였다. 음절구조 유형 수는 2 세 전반에는 평균 6.14개, 2 세 후반 에는 평균 6.91 개로 나타났는데 이는 통계적으로 유의한 것으로 나 타났다. 8 가지 한국어 음절구조 중에서 2 세 전반과 후반 아동 모두 $\mathrm{CV}$ 구조를 $50 \%$ 이상으로 가장 높은 비율로 산출하였고 그 다음으 로 V와 CVC가 $10 \%$ 대의 비율을 차지하였다. 활음이 단모음과 함께 사용된 GVC와 $\mathrm{CGVC}$ 유형의 경우는 전체적으로 적게 산출되었 고, 일부 아동들에게서는 관찰되지 않았다.

자음목록을 초성과 종성 위치별로 나누어 살펴보았을 때 2세 전 반에는 초성과 종성의 자음목록 수가 각각 11.05 개와 3.14 개를 보 이다가 2 세 후반에는 각각 13.61 개와 4.79 개를 보여 유의하게 증가 하였다. 자발화 분석을 통해 18-47개월 아동의 자음목록을 살펴본 $\mathrm{Ha}$ 와 Hwang (2013)의 연구에서는 2세 전반 아동이 초성과 종성 위치에서 자음목록 수가 각각 15.90 개, 4.60 개로 측정되었고, 2 세 후반 아동은 초성과 종성 자음 목록 수가 각각 16.40 개, 4.70 개로 측정되어 본 연구결과보다 다소 높은 수치를 보였다. 이것은 선행연 구에서는 50 발화를 기준으로 분석하되 자발화 내에서 서로 다른 어절 50 발화를 기준으로 분석하여 좀 더 다양한 발화가 포함되었 기 때문에 본 연구에 비해 자음 목록 수가 높게 나타났다고 할 수 있다. 월령집단 내 $50 \%$ 이상의 아동이 2 개 이상의 서로 다른 낱말 에서 산출하는 자음목록을 자세히 살펴보면 종합적으로 2 세 후반 에 한국어의 모든 음소가 대다수의 아동에 의해 산출되고 있음을 제시하고 있다. 구체적으로 초성의 경우 2 세 전반에 파열음/피/, 마 찰음/씨/을 제외한 모든 초성 자음이 자음목록에 포함되었고, 2 세 
후반에는 / 표/과 / 씨 음소가 추가되어 초성 위치에 올 수 있는 한 국어 자음이 모두 자음목록에 포함되었다. 종성 자음목록을 자세 히 살펴보면 2세 전반에는 비음과 유음만이 자음목록에 포함되었 지만 2 세 후반에는 3 개의 종성 파열음이 모두 포함되어 종성 위치 에 올수 있는 한국어 자음이 모두 자음목록에 포함되었다. 이러한 결과는 유음과 비음이 먼저 습득되고 이후에 파열음이 습득된다 고 보고됨을 보여주는 한국어 종성 발달과 관련된 선행연구 결과 (Ha \& Hwang, 2013; Hong \& Pae, 2002; Pae, 1994)와 일관성이 있 다. Hong과 Pae (2002) 연구는 2음절로 구성된 24개 낱말을 이용하 여 음절 종성(/ㅁ, ᄂ, O, ㅂ, ㄱ, ㄹ/)의 자음정확도를 토대로 만 2 세부터 5 세까지 어중 및 어말 종성 발달을 살펴보았기 때문에 연구 방법 면에서 본 연구와 차이가 있다. 그러나 선행연구에서도 종성 자음의 정확도 측면에서 비음 /ㄴ/이 가장 먼저 발달하고 파열음 $/$ 기이 가장 늦게 발달하는 것으로 보고하여 본 연구결과와 비슷한 발달 패턴을 보였다.

아동의 독립적인 조음음운능력을 반영하는 측정치 외에도 성인 의 정확한 산출형태와 직접적으로 비교 분석하는 측정치인 PMLU, PWP, PWC, PCC를 이용하여 말 발달 상황을 살펴보았다. 먼저 아 동이 산출하는 조음의 정확도뿐만 아니라 음절길이 및 복잡도를 반영하는 PMLU는 2세 전반과 후반 간 유의한 차이를 보이지 않았 다. 성인이 산출한 형태의 PMLU와 비교해서 아동의 PMLU가 얼 마만큼 근접한지에 대한 정보를 주는 PWP도 2세 전반은 평균 .86, 2 세 후반은 평균.92로 월령이 증가함에 따라 유의하게 증가하였다. 또한 아동이 산출한 단어 또는 어절 중 정확하게 발음된 비율을 나 타내는 PWC도 2 세 전반 평균 $.55,2$ 세 후반 평균 .69로 2 세 후반에 유의하게 증가하였다. 본 연구와 같이 자발화 분석을 통해 단어 수 준에서 아동의 조음음운능력을 살펴 본 Yoon 등(2013) 연구에서 는 2 세 전반과 후반의 PMLU가 각각 평균 6.37,6.87로 나타났다. 또 한 2 세 전반과 후반의 PWP는 각각 $.86, .89$ 로 $\mathrm{PWC}$ 는 각각 $.45, .53$ 으로 나타나 본 연구와 비슷한 조음음운발달 패턴을 보였다. 종합 적으로 어절을 기본 분석단위로 살펴본 측정치의 결과는 2 세 아동 은 성인의 정확한 어절 산출과 비교해서 $80 \%-90 \%$ 근접하게 어절 의 구조, 길이, 정확도를 지켜 발음하고, 산출한 어절의 대략 $50 \%-$ $70 \%$ 를 정확하게 산출한다고 해석할 수 있다. 개별적인 분절음(자 음)의 정확도를 나타내는 자음정확도의 경우에는 어절을 분석단 위로 한 정확률보다 높게 나타나 2세 전반 평균 $73.22 \%, 2$ 세 후반 $83.25 \%$ 로 월령이 증가함에 따라 유의하게 증가하였다. 이러한 결과 는 자발화에서 2 세 전반과 후반 아동이 각각 $70 \%$ 와 $87 \%$ 의 자음정 확도를 보인다고 보고한 Ha와 Hwang (2013)과 비슷한 수치로서 2 세에 이미 대다수의 아동이 $70 \%$ 이상의 높은 자음정확도를 보이
는 것으로 나타났다. 흥미롭게도 영어권 아동을 대상으로 이루어 진 연구에서도 2 세 초반에 자발화에서 자음정확도가 이미 $70 \%$ 정 도에 도달하였고 2세 후반에는 $80 \%-90 \%$ 의 자음정확도를 보이는 것으로 보고하였다. 또한 언어 표현이 본격적으로 증가하는 1 세 후 반부터 시작해 2 세에 음운 습득이 활발하게 이루어져 3 세 이전에 많은 수의 아동이 명료하고 정확한 말을 할 수 있음을 제시하고 있 다(Bernthal, Bankson, \& Flipsen, 2013; Pollock, 2002; Stoel-Gammon, 1985; Watson \& Scukanec, 1997).

2세 아동의 언어적 특성 중 어휘 영역과 관련하여 50 발화를 기준 으로 서로 다른 낱말 수를 살펴본 결과, 2 세 전반에는 평균 32.38 개, 2 세 후반에는 평균 47.57 개로 월령이 증가함에 따라 표현어휘 수가 증가함을 제시하였다. 또한 50 발화를 기준으로 MLUm과 MLUw 를 분석한 결과, MLUm은 2세 전반 평균 1.90, 2 세 후반 평균 2.40 으로 나타났는데 이는 통계적으로 유의하지 않았다. MLUw는 2세 전반 평균 $1.39,2$ 세 후반 평균 1.69 로 월령집단 간 유의한 차이를 보 였다. 발화길이와 관련해서 초기 문법 및 구문 발달 현황을 살피기 위해 가장 긴 3-10 발화를 이용하여 분석하는 방법이 효율적일 수 있다는 선행연구(Andonova, 2015; de Haan \& Singer, 2010; Harris et al., 1986; Trudeau \& Sutton, 2011)에 따라 50 발화 분석결과와 비 교하기 위해 시범적으로 아동이 산출한 10 발화를 토대로 MLUm 와 MLUw를 추가적으로 분석하였다. 아동이 산출한 50 발화 중 가 장 긴 10 발화를 기준으로 분석한 결과, MLUm은 2세 전반 평균 $3.80,2$ 세 후반 평균 6.02로, MLUw는 2세 전반 평균 2.54, 2 세 후반 평균 3.78 로 발화의 길이에 상관없이 50 발화를 분석한 것보다는 2 세 전 후반의 차이가 보다 더 두드러지게 나타났다. 이러한 두 월령 집단 간 큰 차이는 아동이 산출한 긴 발화의 분석이 초기 언어발달 을 보이는 2 세 아동의 문법형태소 및 구문의 발달 현황을 반영한다 는 선행연구의 제안을 지지하는 결과라 할 수 있다. 또한 50 발화를 통해 보았을 때 MLUm과 MLUw의 차이는 2세 전반에서 2세 후반 으로 가면서.51에서 .71로 약간의 증가가 나타났다. 반면에 가장 긴 10 발화 즉 문법적으로 발전된 발화들만으로 분석한 결과 MLUm 과 $\mathrm{MLUw}$ 의 차이는 2 세 전반에서 2 세 후반으로 가면서 1.26 에서 2.24 로 크게 증가하였다. 이는 2 세 전반에 비해 2 세 후반 아동이 문 법형태소를 더 많이 사용하며, 단순히 50 발화를 분석하는 것보다 가장 긴 10 발화를 분석하는 것이 발달적 차이에서 그 차이가 더 크 게 반영됨을 알 수 있다. 이러한 연구결과는 임상 현장에서 3-10개 로 적은 수이지만 가장 긴 발화만을 분석하더라도 아동의 언어 발 달과 중재 효과를 효율적으로 평가할 수 있음을 제안한다. 후속연 구를 통해 가장 긴 10 개의 발화만을 분석하는 것의 효율성과 타당 성을 보다 더 체계적으로 검증하는 것이 필요하다. 또한 2 세 아동 
이 자발화에서 어떤 문법형태소를 어떻게 사용하고 있는지 문법형 태소의 발달적인 측면을 좀 더 구체적으로 살펴볼 필요가 있다.

MLUm과 MLUw와 관련된 결과는 아동의 자발화 샘플링과 표 본크기에 따라 발화길이 측정치가 비교적 큰 폭으로 변할 수 있음 을 제시한다. 본 연구에서 50 발화를 기준으로 분석한 MLUm과 $\mathrm{MLUw}$ 수치는 2세 한국아동의 발화길이를 보고한 선행연구결과 와 비교했을 때 낮은 경향을 보인 반면에 가장 긴 발화 10 발화에서 분석된 수치는 선행연구결과보다는 높은 경향을 보였다(Jung \& Yoon, 2013; Kim, 1997; Yoon et al., 2013). 예를 들어 Kim (1997) 연 구의 경우 2세 전반과 후반의 MLUm은 각각 3.01과 3.75로 $\mathrm{MLUw}$ 는 각각 2.27 과 2.67로 보고하였다. 또한 본 연구에서 분석된 50 발 화와 가장 긴 10 발화에서의 분석치의 상관분석을 실시한 결과 50 발화와 10 발화 간 $\mathrm{MLUm}$ 와 $\mathrm{MLUw}$ 의 상관계수는 각각 .57과 .64 로 나타났다. 두 상관계수 모두 통계적으로 유의하였으나 비교적 낮은 상관관계를 보였다. 이러한 발화길이가 차이가 나는 이유로는 대상자 및 자발화 샘플링 조건, 표본크기와 관련이 있을 수 있다. 특 히 본 연구에서는 아동의 언어발달뿐만 아니라 말 발달을 동시에 살펴보고자 하였기 때문에 자발화 수집 과정에서 동일한 단어를 여러번 반복해서 유도한 경우가 있다. 따라서 언어발달에 초점을 둔 선행연구들에 비해 MLU가 과소평가되었을 가능성도 있어 해 석 시 주의가 필요하다. 따라서 아동의 언어발달 현황과 능력을 타 당하게 대표하고 아동의 언어발달과 중재 효과를 신뢰롭게 반영할 수 있는 적절한 자발화 표본크기와 수집 조건에 대한 추후 면밀한 조사가 필요할 것으로 생각된다.

본 연구에서는 모든 측정치에 관해서 월령뿐만 아니라 성별 간 의 차이도 살펴 보았는데, 기술통계상으로는 모든 측정치에서 여아 가 남아보다 높은 수치를 보이는 것으로 나타났으나 통계적으로는 모두 유의한 차이를 보이지 않는 것으로 나타났다. 말-언어 습득상 에서 성별의 차이를 살펴본 선행연구들은 다양한 결과를 제시하였 다(Bernthal et al., 2013; Fenson et al., 1994; Hoff, 2005; Huttenlocher, Haight, Bryk, Seltzer, \& Lyons, 1999). 많은 연구들이 상반된 결과를 제시하고 있지만, 성별 간의 유의미한 차이가 있다면 말-언 어 습득이 활발하게 이루어지는 시기가 여아와 남아에 따라 다소 다르고, 말-언어장애로 확인될 확률은 남아에게서 더 높다는 연구 결과가 일반적이다. 본 연구에서 2 세 후반 집단에 상대적으로 적은 수의 남아가 참여하여 연구결과 해석에 주의를 기울여야 한다. 한 국 2 세 아동의 일반적인 말-언어발달 현황을 제시하기 위해서 더 많은 아동을 대상으로 여아와 남아의 말-언어습득 패턴을 살펴보 고 상대적으로 말-언어발달이 활발한 시기가 성별에 따라 서로 다 른지 자세히 살펴보는 것이 필요하다고 생각된다.
본 연구의 모든 언어 측정치는 연구자들이 개발한 웹 기반 KLA 소프트웨어 프로그램(kla.hallym.ac.kr)을 통해 자동으로 분석되 었다. KLA는 전사자가 아동의 발화를 낱말과 내용 및 문법형태소 의 경계를 나누어 특정 기호로 표시하여 프로그램에 입력한 것을 토대로 측정치가자동으로 계산되기 때문에 전사자의 전사 및 코딩 의 정확도가 중요하다. 즉 전사자가 아동이 산출한 언어의 어휘, 형 태소, 구문에 대한 지식과 판단이 중요하다. 이 점은 컴퓨터가 아동 발화를 기계적으로 자동 분석하는 것보다는 전사자가 발화 수집 상에서 아동이 표현한 발화의 성격과 상황을 고려하여 아동의 언 어 특성을 의미있게 반영할 수 있다는 장점이 있다. 특히 일반적인 발화 특성에서 벗어난 의사소통장애 아동의 다양한 언어 특성을 전사자와 평가자가 고려하고 반영하여 분석할 수 있다. MLU와 같은 객관적인 측정치뿐만 아니라 아동 발화의 오류를 별도로 표시하여 분석할 수 있고 아동이 산출한 형태소 유형 및 빈도 수를 자동으로 계산할 수 있다. 따라서 $\mathrm{KLA}$ 는 시간적인 제약으로 인해 아동의 자 발화를 자세하게 분석하지 못하고 표준화된 검사도구만을 사용하 고 있는 임상 현장에 유용하게 사용될 수 있을 것으로 기대된다.

결론적으로 본 연구는 대부분의 말-언어 측정치에서 2 세 전반과 후반에서 유의한 차이를 보여 2 세 동안 아동은 빠르게 새로운 어 휘를 습득해나가고 문법형태소를 사용하여 긴 발화를 산출하기 시작하고 동시에 비교적 높은 명료도와 정확도로 말소리를 산출해 나감을 제시하고 있다. 본 연구결과는 체계적인 자발화 분석을 통 한 2 세 한국아동의 말-언어 발달에 관한 객관적인 자료로서, 빠른 속도로 말-언어발달을 이루면서 아동간 상대적으로 큰 개인차를 보여 지연이나 장애 여부를 판단할 때 어려움이 있었던 2 세 아동의 평가에 유용하게 사용될 수 있을 것이다. 자발화 분석결과를 토대 로 표준화된 말-언어 검사도구를 보완하여 말-언어발달 지연 및 의 사소통장애를 보다 더 정확하게 확인하고 언어중재서비스의 필요 성을 적절하게 결정하는 데 유용한 기초자료로서 활용될 수 있을 것이다.

\section{REFERENCES}

Andonova, E. (2015). Parental report evidence for toddlers' grammar and vocabulary in Bulgarian. First Language, 35, 126-136.

Bernthal, J. E., Bankson, N. W., \& Flipsen, P. (2013). Articulation and phonological disorders: speech sound disorders in children (7th ed.). Boston, MA: Pearson.

Choi, M. S., Kim, S. J., \& Kim, H. S. (2014). Lexical and phonology development in 2-year-old Korean children. Korean Journal of Early Childhood 
Special Education, 14, 133-152.

Cole, K. N., Mills, P. E., \& Dale, P. S. (1989). Examination of test-retest and split-half reliability for measures derived from language samples of young handicapped children. Language, Speech, and Hearing Services in Schools, 20, 259-268.

deHaan, D., \& Singer, E. (2010). The relationship between young children's linguistic ability, home language, and their adaptive modifying strategies in peer conflicts. First Language, 30, 421-439.

Fenson, L., Dale, P. S., Reznick, J. S., Bates, E., Thal, D. J., Pethick, S. J., ... \& Stiles, J. (1994). Variability in early communicative development. Monographs of the Society for Research in Child Development, 59, 1-185.

Ha, S., \& Hwang, J. (2013). Speech measures from phonological analyses of spontaneous conversations in children between 18-47 months of age. Communication Sciences \& Disorders, 18, 425-434.

Harris, M., Jones, D., Brookes, S., \& Grant, J. (1986). Relations between the non-verbal context of maternal speech and rate of language development. British Journal of Developmental Psychology, 4, 261-268.

Hoff, E. (2005). Language development (3rd ed.). Belmont, CA: Wadsworth/ Cengage Learning.

Hong, J. H., \& Pae, S. (2002). The coda error patterns of children aged from 2 to 5. Korean Journal of Communication Disorders, 7, 297-307.

Huttenlocher, J., Haight, W., Bryk, A., Seltzer, M., \& Lyons, T. (1991). Early vocabulary growth: relation to language input and gender. Developmental Psychology, 27, 236-248.

Ingram, D. (2002). The measurement of whole-word productions. Journal of Child Language, 29, 713-733.

Ingram, D., \& Ingram, K. D. (2001). A whole-word approach to phonological analysis and intervention. Language, Speech, and Hearing Services in Schools, $32,271-283$.

Jung, Y. H., \& Yoon, M. S. (2013). Mean length of utterance for typically developing children of 2 to 4 years. Korean Journal of Early Childhood Special Education, 13, 55-73.

Kim, M. J., Kim, S. J., Ha, J. W., \& Ha, S. (2015). A survey of co-morbidity and speech-language characteristics in speech sound disorders. Communication Sciences \& Disorders, 20, 446-455.

Kim, Y. T. (1997). Foundation of length of utterance in 2 to 4 year-old children. Korean Journal of Communication Disorders, 2, 5-26.

Kim, Y. T. (2014). Diagnosis and treatment of language disorders in children (2nd ed.). Seoul: Hakjisa.

KLA (Korean Language Analysis) [Computer software] kla.hallym.ac.kr, Hal- lym University, Korea.

Lee, H. R. (2004). A study of early subject acquisition in Korean. Korean Journal of Communication Disorders, 9, 19-32.

Lee, H. R., Chang, Y. K., Choi, Y. L., \& Lee, S. (2008). Acquisition of grammatical function words in Korean Children. Korean Journal of Communication Disorders, 13, 159-173.

Lee, S., \& Lee, H. R. (2006). Amazing language development with children. Seoul: Jeongdam Media.

SALT: Systematic Analysis of Language Transcripts (Version 8.0) [Computer software]. Madison, WI: University of Wisconsin, Waisman Center.

Moon, H., \& Ha, S. (2012). Phonological development in toddlers with cleft palate and typically developing toddlers aged 12-24 months. Korean Journal of Communication Disorders, 17, 118-129.

Pae, S. (1994). Development of normal speech. In Korean Academy of SpeechLanguage Pathology and Audiology (Ed.), Treating articulation disorders children (pp. 27-53). Seoul: Koonja Publishing Inc.

Pae, S. (2003). Validity and reliability of the Korean adaptation of MCDI. Korean Journal of Communication Disorder, 8, 1-14.

Pae, S. (2006). Grammatical development of Korean young children. Korean Linguistics, 31, 31-45.

Pae, S., \& Kwak, K. C. (2011). Korean MacArthur-Bates Communicative Development Inventories (KM-B CDI). Seoul: Mindpress.

Pae, S., Chang, Y. K., Kwak, K. J., Sung, H. R., \& Sim, H. O. (2004). MCDI-K referenced expressive word development of Korean children and gender differences. Korean Journal of Communication Disorder, 9, 45-56.

Pae, S., Kim, K. S., Sung, K. H., \& Sung, J. A. (1998). Computer and language assessment: Korean Computerized Language Analysis 1.0. Korean Journal of Communication Disorder, 3, 123-137.

Paul, R., \& Norbury, C. (2012). Language disorders from infancy through adolescence (4th ed.). St. Louis, MO: Mosby.

Pollock, K. E. (2002). Identification of vowel errors: methodological issues and preliminary data from the Memphis Vowel Project. In M. J. Ball \& F. E. Gibbon (Eds.), Vowel disorders (pp. 83-113). Boston, MA: ButterworthHeinemann.

Seo, H. S., \& Lee, S. H. (1999). The development of connective endings of 2-5 year old normal children. Korean Journal of Communication Disorder, 4, 167-185.

Shriberg, L. D., \& Kwiatkowski, J. (1982). Phonological disorders III: a procedure for assessing severity of involvement. Journal of Speech and Hearing Disorders, 47, 256-270. 
Stoel-Gammon, C. (1985). Phonetic inventories, 15-24 months: a longitudinal study. Journal of Speech, Language, and Hearing Research, 28, 505-512.

Trudeau, N., \& Sutton, A. (2011). Expressive vocabulary and early grammar of 16- to 30-month-old children acquiring Quebec French. First Language, 31, 480-507.

Watson, M., \& Scukancec, G. (1997). Profiling the phonological abilities of 2-year-olds: a longitudinal study. Child Language Teaching and Therapy,
13, 3-14.

Yoon, M. S., Kim, J. M., \& Kim, S. J. (2013). Phonological whole-word measures of spontaneous speech in children two to four years of age. Journal of Speech-Language \& Hearing Disorders, 22, 69-85.

Yoon, M. S., Kim, S. J., Kim, J. M., Chang, M. S., \& Cha, J. E. (2013). Reliable sample size for mean length of utterance analysis in preschooler. Communication Sciences \& Disorders, 18, 368-378. 


\title{
국문초록
}

\section{자발화 분석을 통한 만 2 세 한국아동의 말-언어발달 특성}

\author{
하승희 ${ }^{1} \cdot$ 설아영 ${ }^{2} \cdot$ 소정민 ${ }^{3} \cdot$ 배소영 ${ }^{1}$
}

1한림대학교 언어청각학부 청각언어연구소, ${ }^{2}$ 한림대학교 일반대학원 언어병리학과, ${ }^{3}$ 한림대학교 컴퓨터공학과

배경 및 목적: 본 연구는 자발화 분석을 통해 음운, 의미, 구문, 형태론을 나타내는 객관적인 지표를 구해 월령집단과 성별에 따라 다른 지 살펴보면서 2 세 한국아동의 말-언어발달 특성을 자세히 살펴보았다. 또한 아동의 자발화 분석을 용이하게 하기 위해 개발된 한국어 발화 분석기(Korean Language Analysis, KLA) 프로그램을 이용해서 객관적인 측정치를 제시하면서 프로그램의 효율성을 소개하고자 하였다. 방법: 출생과 발달상의 특이사항이 없는 생후 24-30개월 된 일반아동 21명, 생후 31-36개월 된 일반아동 23명으로부터 50 발화 를 수집하여 분석하였다. 객관적인 말 지표로서 자음목록, 음절구조 유형 수, 평균음운길이, 단어단위 근접률, 단어단위 정확률, 자음 정확도를 분석하였다. 언어지표는 한국어 발화분석 프로그램을 이용하여 서로 다른 낱말 수, 총 사용 낱말 수, 평균형태소길이, 평균낱 말길이를 분석하였다. 결과: 2 세 전반과 후반의 월령집단과 성별에 따라 말 특징을 살펴본 결과 평균음운길이를 제외한 모든 측정치에 서 2세 전반과 후반 아동이 유의미한 차이를 보였다. 언어 특징을 나타내는 측정치인 서로 다른 낱말 수와 총 낱말 수, 평균낱말길이 면 에서 월령집단별 유의미한 차이가 관찰되었다. 성별 간 차이는 모든 말-언어 측정치에서 유의하지 않았다. 논의 및 결론: 본 연구결과, 자 발화 분석을 통한 2 세 아동의 객관적인 자료는 말-언어발달지연 및 의사소통장애 여부를 평가할 때 기초자료로 활용될 수 있을 것이다.

핵심어: 2 세, 말-언어 발달, 객관적인 발달지표, 자발화, 한국어 발화 분석 프로그램

한림대 언어병리학과 대학원생 박보라, 피민경, 이다은, 김혜지, 정소미가 자료 수집과 분석에 참여하였음.

\section{참고문헌}

김민정, 김수진, 하지완, 하승희(2015). 말소리장애의 동반장애 유형 및 말-언어 특성에 관한 설문조사. 언어청각장애연구, 20, 446-455. 김영태(1997). 한국 2-4세아동의 발화길이에 관한 기초연구. 말-언어장애연구, 2, 5-26.

김영태(2014). 아동언어장애의 진단 및 치료(제2판). 서울: 학지사.

문희원, 하승희(2012). 12-24개월 구개열 유아와 일반 유아의 음운발달. 언어청각장애연구, 17, 118-129.

배소영(1994). 정상 말소리 발달. 한국언어병리학회(편). 아동의 조음장애 치료(pp. 27-53). 서울: 군자출판사.

배소영(2003). 영유아기 의미평가도구 MCDI-K의 타당도와 신뢰도에 관한 연구. 언어청각장애연구, 8, 1-14.

배소영(2006). 한국어 발달특성과 학령전기 문법형태소. 한국어학, 31,31-45.

배소영, 곽금주(2011). 맥아더-베이츠 의사소통발달 평가(K M-B CDI). 서울: 마인드프레스.

배소영, 김광선, 성경훈, 성진아(1998). 컴퓨터와 언어능력 진단평가: Korean Computerized Language Analysis 1.0. 언어청각장애연구, 3, 123-137.

배소영, 장유경, 곽금주, 성현란, 심희옥(2004). MCDI-K를 통해 본 한국유아의 표현어휘발달과 성차. 언어청각장애연구, 9, 45-56.

서희선, 이승환(1999). 2-5세 정상 아동의 연결어미 발달. 언어청각장애연구, 4, 167-185.

윤미선, 김수진, 김정미, 장문수, 차재은(2013). 평균발화길이 분석을 위한 발화 표본의 크기. 언어청각장애연구, 18, 368-378.

윤미선, 김정미, 김수진(2013). 자발화 문맥에서의 단어단위 음운 평가: 2-4세 아동. 언어치료연구, 22, 69-85.

이승복, 이희란(2006). 아이와함께하는 신기한 언어발달. 서울: 정담미디어.

이희란(2004).2세 한국아동의 주어 발달 특성. 언어청각장애연구, 9, 19-32.

이희란, 장유경, 최유리, 이승복(2008). 부모보고를 통해 종단관찰 한 한국 아동의 초기 문법형태소 습득 언어청각장애연구, 13, 159-173.

정윤희, 윤미선(2013). 2,3,4세 일반 아동의 평균발화길이. 유아특수교육연구, 13, 55-73.

최민실, 김수진, 김효선(2014). 2세 전 후반의 어휘능력과 음운능력. 유아특수교육연구, 14, 133-152.

하승희, 황진경(2013). 18-47개월 아동의 자발화 분석에 기초한 말소리 측정치에 관한 연구. 언어청각장애연구, 18, 425-434.

홍진희, 배소영(2002).2세부터 5세 아동의 종성 발달에 관한 연구. 언어청각장애연구, 7, 293-304. 